\title{
As Tecnologias Digitais Móveis no Processo de Letramento Visual: uma experiência com o app Pics Art
}

\author{
Sandra Virgínia Correia de Andrade SANTOS* \\ Anne Alilma Silva Souza FERRETE** \\ Derli Machado de OLIVEIRA***
}

\begin{abstract}
* Doutoranda em Educação pela Universidade Federal de Sergipe (UFS). Mestra (2015) em Língua Portuguesa pela Universidade Federal de Sergipe. Professora da educação básica. Membro dos Grupos de Pesquisa Educação e Culturas Digitais-Ecult e Estudos em Educação Superior-GEES.Contato: sanlitera@yahoo.com.br

** Doutora (2007) em Educação pela Universidade Federal do Rio Grande do Norte. Mestra (2002) em Educação pela Universidade Federal de Sergipe (UFS). Docente da Universidade Federal de Sergipe (UFS). Professora permanente do Programa de PósGraduação em Educação (UFS). Contato: aferrete21@gmail.com

*** Doutor (2013) em Estudos da Linguagem pela Universidade Federal do Rio Grande do Norte (UFRN). Mestre (2010) pela Universidade Federal de Sergipe (UFS). Professor Adjunto na Universidade Federal de Sergipe, no Departamento de Letras. Contato: derli_machado@hotmail.com.
\end{abstract}

\section{Resumo:}

Este artigo traz reflexões sobre a utilização das tecnologias digitais móveis e de seus aplicativos (apps) nas práticas de sala de aula, a partir de um trabalho desenvolvido em uma escola pública do estado de Sergipe. Com o objetivo de desenvolver a competência leitora dos elementos multimodais presentes no gênero capa de revista, a proposta didáticopedagógica partiu de atividades realizadas com o smartphone, de modo a fomentar e desenvolver o letramento visual. Para o alcance dos resultados, fora utilizado o aplicativo PicsArt, o qual permitiu a apropriação dos alunos diante dos elementos que compõem as capas de revista e seus sentidos. Tendo adotado como método científico o estudo de caso, com abordagem qualitativa, a pesquisa, além de abordar e analisar a experiência, sinaliza também os desafios enfrentados ao se inserir tais recursos no contexto educacional, bem como as possibilidades e a importância de se trabalhar as múltiplas linguagens por meio das tecnologias digitais móveis e de seus apps.

\section{Palavras-chave:}

Tecnologias Digitais Móveis. Letramento visual. PicsArt.

Signum: Estudos da Linguagem, Londrina, v. 23, n. 1, p. 113-132, abr. 2020 


\title{
As Tecnologias Digitais Móveis no Processo de Letramento Visual: uma experiência com o app PicsArt
}

\author{
Sandra Virgínia Correia de Andrade Santos; Anne Alilma Silva Souza Ferrete; \\ Derli Machado de Oliveira
}

\section{INTRODUÇÃo}

Na composição textual contemporânea, a presença de múltiplas linguagens é algo marcante, destacandose, em especial, as utilizadas a partir das inovações tecnológicas, as quais impulsionam cada vez mais a utilização de um repertório multimodal e, inclusive, multimidiático. Nos textos com os quais o leitor se depara, atualmente, encontra-se facilmente, além da linguagem verbal, uma linguagem visual que tem influenciado e modificado tanto os modos de leitura quanto os de escrita, constituindo novas possibilidades no cotidiano escolar. Nesse cenário, as pesquisas sobre a linguagem apontam a leitura visual como um processo significativo dentro da sala de aula, uma vez que a cultura digital coloca à disposição do indivíduo diversos recursos semióticos, os quais dinamizam a composição textual contemporânea e constituem sentidos. Por outro lado, mesmo diante da presença ativa da imagem nas relações sociocomunicativas, percebe-se que, na educação básica, a interação entre o texto escrito e a imagem é pouco explorada, realidade observada por meio dos resultados iniciais deste estudo. ${ }^{1}$ Para os estudantes, sujeitos desta pesquisa, a imagem apenas ilustra o que está escrito, não havendo, portanto, um diálogo que interage e complementa. Além disso, para esses mesmos alunos, a linguagem visual está associada apenas à imagem principal, sem perceber que há uma multimodalidade e que suas escolhas compõem o sentido do texto, seja a partir da posição que ocupa, seja por cores, formatos, personagens presentes etc.

Diante dessa realidade, o presente estudo foi desenvolvido com alunos do oitavo ano do Ensino Fundamental, em uma escola pública localizada no município de Tobias Barreto, Sergipe, tendo como método de pesquisa o estudo de caso que, de acordo com Gil (1999), configura-se em um método que permite investigar um grupo, uma organização ou um fenômeno com abordagem qualitativa. Essa proposta envolveu 38 alunos, os quais participaram ativamente de todo o processo, seja discutindo, exercitando ou produzindo. Os instrumentos escolhidos para produção dos dados foram a aplicação de questionário, a observação espontânea, sistemática e participativa das aulas de Língua Portuguesa, bem como as atividades realizadas pelos alunos. Para garantir a não identificação dos participantes, a referência individual foi feita por meio de iniciais sugeridas pelos próprios alunos e, para a referência coletiva, a inicial D seguida do número correspondente à dupla, já que a proposta envolveu práticas tanto individuais quanto coletivas. Nesse contexto, foram elaborados materiais, estratégias e recursos, que fizeram parte do planejamento a ser desenvolvido em sala de aula sobre o gênero textual capa de revista, tendo em vista sua composição multimodal repleta de semioses que se misturam e se conectam para um todo coerente. Essa proposta partiu da necessidade de desenvolver junto aos alunos a competência leitora diante dos textos multimodais, com apoio de seus smartphones, já que esses dispositivos possibilitam e potencializam a participação ativa dos alunos tanto no processo de produção de textos multimodais

\footnotetext{
${ }^{1}$ Este artigo é um recorte da pesquisa de mestrado desenvolvida a partir da realização de um projeto pedagógico envolvendo o gênero textual capa de revista no processo de letramento visual. Disponível em: https://bit.ly/3pn8Mc5
} 
quanto no de leitura e de compreensão. Para isso, o aplicativo PicsArt foi escolhido e instalado nos smartphones dos alunos que, com ele, puderam potencializar, a partir da sua própria construção visual, habilidades tanto tecnológicas quanto leitoras.

Para dialogar com essas questões, tem-se como aporte teórico as discussões de Kress e van Leeuwen (1996), Moreira e Massini (2001), Aquino e Souza (2008), Bamford (2009), Dionísio (2011) e Costa (2013), dentre outros. Esse artigo, portanto, traz reflexões sobre o letramento visual e a utilização das tecnologias digitais móveis nesse processo, provocando, assim, discussões importantes no contexto da sala de aula.

\section{A Gramática do Design Visual no Processo de Letramento Visual}

$\mathrm{Na}$ cultura ocidental, a linguagem verbal sempre foi considerada um modo dominante de comunicação; no entanto, as mudanças ocorridas nas relações sociocomunicativas têm colocado a linguagem não verbal (aquela que não se utiliza de palavras) em uma posição também significativa. Considerava-se a linguagem verbal, fosse ela oral ou escrita, como principal modo semiótico no processo comunicativo; na contemporaneidade, a não verbal tem evidenciado seu papel discursivo e determinante para a construção de sentido.

Diante da densidade de imagens que permeiam a sociedade atual, tanto nas mídias impressas quanto nas digitais, compreender sua representatividade e os efeitos de sentido provocados pelas escolhas visuais capacita os praticantes culturais a observar e a interpretar o mundo.

Desde a história mais remota, conhecida pelo homem, a imagem marca sua presença de forma inegável, e através dela o ser humano se expressa desde muito tempo antes da palavra escrita. Sua cultura se fortaleceu através da significação que estas imagens estabeleceram durante o percurso nas mais diversas épocas. E, atualmente, o mundo nos cerca de imagens durante todo o tempo, mensagens visuais que estão sendo estudadas e investigadas por diversas disciplinas de pesquisa (SPENGLER, 2010, p. 1).

Daí surge a necessidade de compreender tais escolhas visuais, qual sua real significação e, inclusive, promover sua ressignificação, pois não há uma presença aleatória de elementos. O que se encontra é uma arquitetura produzida para se chegar a um todo coerente e significativo, uma vez que, comunicar-se por meio de imagens, atualmente, é algo tão corriqueiro que é comum a integração entre o texto verbal e as imagens em várias esferas discursivas, sejam elas profissionais e/ou pessoais.

Diante disso, para compreender a composição imagética presente em várias situações comunicativas, é possível lançar um olhar para a Gramática do Design Visual, a GDV, que analisa linguística e estruturalmente os textos visuais e seus códigos semióticos a partir de uma tríade: a representação do mundo, a interação entre leitor e texto e a significação de suas escolhas visuais, ou melhor, as imagens, as quais, segundo a GDV, justapõem três perspectivas: representação, interação e significação.

Reconhecer que as imagens não só possuem estrutura, mas, principalmente, apresentam sentido possibilita a criação de leitores mais críticos diante das manifestações discursivas e das novas identidades sociais que o universo tecnológico tem despertado. A visão multifuncional das escolhas linguísticas verbais e visuais permite compreender os modos como a linguagem é utilizada para o atendimento de diferentes propósitos e para a funcionalidade em diferentes contextos.

Kress e van Leeuwen (1996) apontam para a necessidade de promover o letramento visual partindo de práticas pedagógicas mais efetivas quanto ao desenvolvimento do aprendiz nas capacidades de questionar, interpretar e criticar. Para isso, o reconhecimento das estruturas visuais deve fazer parte desse novo olhar, pois a combinação entre o verbal e o não verbal é responsável pela construção de sentido global do texto. Ou 
melhor, a leitura integrada dos códigos semióticos que viabilizam a construção de enunciados contemporâneos e multimodais focaliza modos, meios e práticas comunicativas e discursivas, preparando a sociedade para novas habilidades.

Como possibilidade para uma melhor compreensão sobre esse processo imagético, Kress e van Leeuwen (1996) descrevem e discutem três metafunções. A primeira delas é chamada de representacional. Sua significação está em o leitor, ao entrar em contato com o texto visual, observar que há, na composição imagética, participantes representados, sejam eles pessoas, objetos ou lugares "conectados por um vetor, [que] determina aquele que faz e aquele a quem a ação é dirigida” (FERNANDES; ALMEIDA, 2008, p. 13). Nela, constrói-se a natureza dos eventos, objetos, participantes envolvidos e as circunstâncias, ou seja, "enfatiza a representação de aspectos do mundo - físico, mental, social” (OTTONI; LIMA, 2014, p. 31). Essa metafunção relaciona-se com o conteúdo das imagens e, diante disso, pode apresentar duas possíveis estruturas - a narrativa e a conceitual -, diferenciando-se pela presença ou ausência de ações.

A segunda é a metafunção interativa, a qual estabelece estratégias de aproximação ou afastamento entre o produtor do texto e o seu interlocutor, pois, por meio dela, percebe-se o nível de envolvimento presente em sua construção. Nessa construção de sentido, o olhar do observador engaja-se em uma relação de ligação ou não entre os participantes do processo, significando aquilo que "fundamenta a relação entre as imagens e o público-alvo" (OUVERNEY, 2008, p. 50).

Por último, tem-se a metafunção composicional, responsável pela organização e pela combinação entre as metafunções anteriores. Ao analisar as duas primeiras, identifica-se o que está presente na composição imagética, sua representação e efeito diante do leitor. Nesta, passa-se a compreender a construção de sentido de tais elementos, observando suas escolhas e estruturação. Portanto,

A leitura da imagem não é um mergulho no desconhecido, pois o autor organizou sua obra de maneira a que ela seja lida pelo observador: ele criou um recorte; hierarquizou as figuras; com a luz colocou certos aspectos em evidência, encobrindo outros; aproximou certos elementos do público, deixando outros ao fundo. Ele orienta o observador por meio de gestos emprestados às figuras e de linhas e movimentos pelos quais nosso olhar se esgueira (COSTA, 2013, p. 63).

Destarte, fica evidente que a linguagem visual apresenta claramente normas e estruturas que contribuem para sua construção de sentido. Assim como todas as outras, a linguagem visual estrutura-se para a construção de sentido, corroborando para a presença de um novo texto. No entanto, para a compreensão significativa do texto visual, é necessário identificar os elementos construtores de seu sentido, bem como compreender suas normas e estruturas semióticas, capacitando cada vez mais o seu observador para novas leituras visuais e habilitando o indivíduo quanto aos aspectos linguísticos de um texto, seja ele verbal ou visual.

Assim, por meio do aprofundamento da Gramática do Design Visual, é possível tornar real o novo letramento em questão na atualidade, o letramento visual, pois, com a GDV, o leitor não vai olhar para a imagem sem se debruçar com os elementos responsáveis pela situação comunicativa e seus vários significados. Nesse sentido, por perceber que as práticas de leitura contemporâneas são marcadas pela abundância da oferta de textos e pela diversidade de suas formas de reprodução, suportes e organização textual, gráfica e visual compreende-se que, cabe à educação a responsabilidade direta de incentivar seus alunos a novas leituras, mostrando-lhes as sutilezas e as entrelinhas dos textos para que alcancem o domínio da diversidade linguística que circulam na sociedade. 


\section{A Leitura Visual da Capa de Revista À Luz da GDV}

A revista Mundo Estanho ${ }^{2}$ era um periódico que tinha como meta aguçar a curiosidade de seus leitores. Produzida de 2001 a 2018, aos poucos foi conquistando os leitores devido a suas temáticas estarem relacionadas às curiosidades científicas e culturais. Tendo como foco o público jovem, preocupava-se em trazer à tona respostas para as várias perguntas feitas por esse público-alvo, por meio da seção de perguntas. Mensalmente produzida, trazia não só na capa, mas em todo o seu interior, em cada edição, uma multimodalidade marcante, muitas vezes com elementos bizarros que definiam o estilo surpreendente da revista. Além de adquiri-la através das bancas de revista ou por assinatura, o leitor podia entrar em contato também por meio do site, local virtual onde qualquer internauta tem acesso às suas edições, permitindo uma interação ativa e, inclusive, atrativa. Hoje, a revista encontra-se disponível no site da revista Superinteressante. ${ }^{3,4}$

Reconhecendo, portanto, o periódico Mundo Estranho como um suporte repleto de multimodalidade, a análise de sua capa terá como abordagem as metafunções, que refletem sobre os sentidos que cada escolha visual e verbal apresenta, como se observa na Figura 1, a seguir.

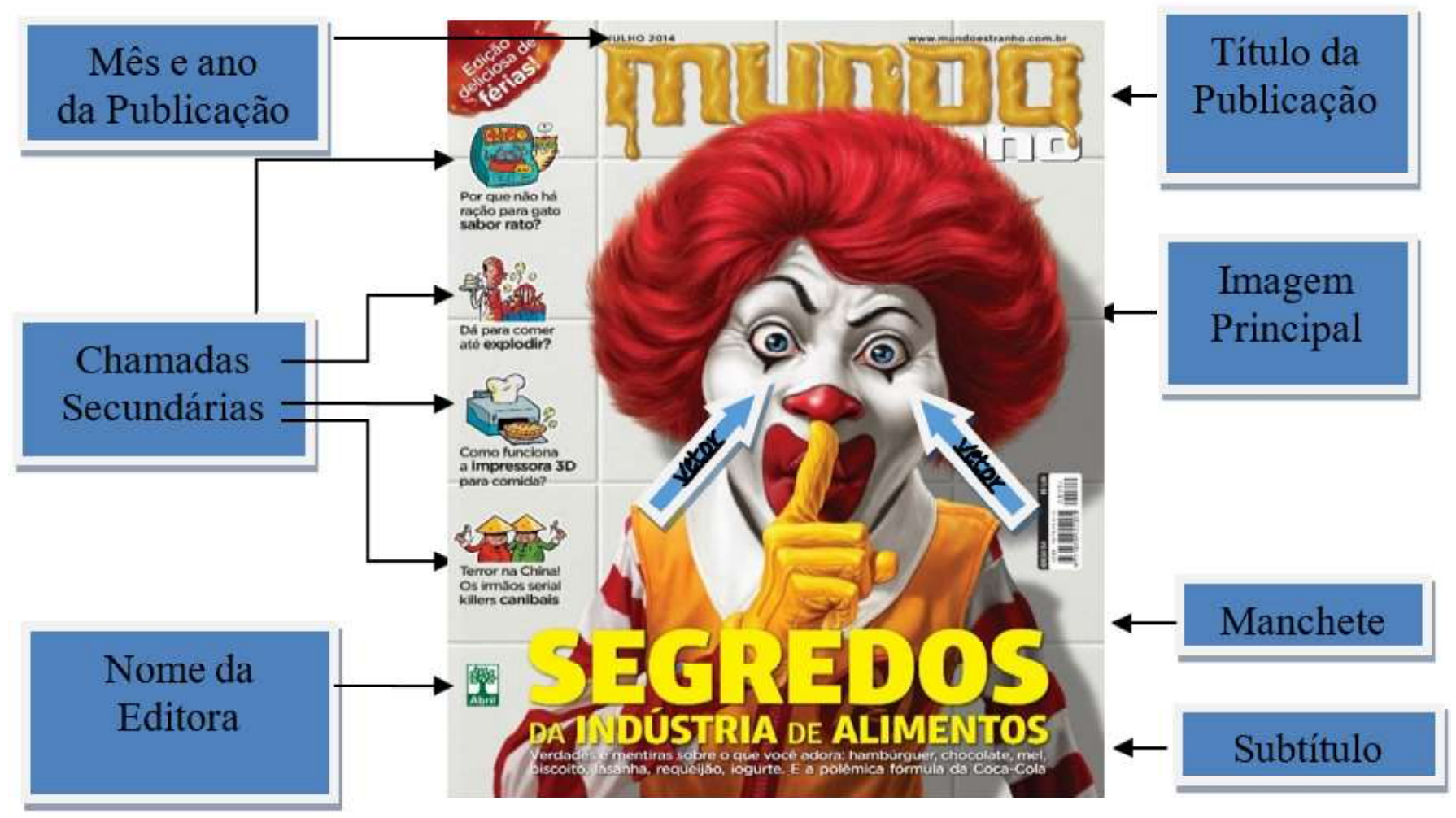

Fonte: Mundo Estranho, edição 154, jul. 2014.

Figura 1 - Capa da revista Mundo Estranho

Iniciando pela metafunção representacional, o leitor começa a observação identificando se há ação representada ou não e quem é o participante representado. No caso da capa da revista Mundo Estranho escolhida

\footnotetext{
2 Para este estudo foram trabalhadas algumas capas de revista, tanto impressas quanto digitais. Uma delas foi a revista Mundo Estranho, a qual fora selecionada para esta discussão.

${ }^{3}$ A revista Mundo Estranho, que era publicada mensalmente, foi descontinuada em 2018.

${ }^{4}$ A revista Superinteressante, em seu site, ainda publica conteúdo da revista Mundo Estranho. Disponível em: bit.ly/2Y7lMGx.
} 
para esta análise, o leitor identifica que, através do participante representado, há uma ação sendo realizada; portanto, encontra-se o processo narrativo. A partir daí, iniciam-se novas inferências. Nesse momento, identificase também a presença do vetor, que liga o olhar do participante representado ao do participante interativo - o observador. O vetor é um traço indicativo da direcionalidade do olhar - apontando linearmente para seu interlocutor. As linhas e as pontas das flechas, representantes do vetor, indicam a direção do movimento dos participantes, assinalando aquele que faz e aquele a quem a ação se destina. Além do olhar, há uma volumetria destacando a expressão facial que favorece a identificação do ser representado. Assim, com a leitura visual, o leitor percebe que se trata não de um palhaço qualquer, mas de Ronald McDonald, personagem de uma das maiores redes de fast-food mundial.

Ao observar a capa da edição 154 da revista Mundo Estranho, o interlocutor sente-se preso ao olhar do participante, pois, independentemente do ângulo que se olhe, o vetor irá acompanhá-lo, promovendo, portanto, uma interação permanente. Nesse caso, a Semiótica aponta para um participante interativo, já que, além de ser sujeito da comunicação, interage com o leitor. Portanto, na metafunção interativa, tem-se a demanda, o olhar direcionado para o leitor, uma vez que o participante encontra sua meta: o leitor. Nesse processo, identifica-se que o ator desempenha uma ação imperativa no momento que solicita silêncio do seu interlocutor. Já no processo de reação, o participante representado chama-se reator, o qual encontra o seu fenômeno, o participante observado, ou seja, o leitor.

Os elementos visuais que permitem essa observação são os responsáveis pela atração de seu observador não só para a leitura da capa, mas para os sentidos que são inferidos. Ao olhar para seu fenômeno, o reator provoca a sensação de intimidação. Embora o símbolo de pedido de silêncio esteja representado, a junção com a expressão e com outros elementos indica uma relação de poder ameaçador. Esse jogo de significados é compreensível quando se observam os elementos utilizados para atender a uma proposta discursiva. Ainda a respeito da metafunção representacional, a manutenção de suas características peculiares - como a fisionomia, as cores e todos os outros elementos visuais - permite reconhecer a figura de Ronald McDonald numa situação misteriosa quando se confronta o personagem retratado, sua expressão e o local onde se encontra. Além disso, ao se cruzar os elementos visuais analisados até aqui e os elementos verbais presentes na manchete e no subtítulo, percebe-se que o participante representado dialoga com o verbal construindo, portanto, novos e complementares sentidos.

A palavra SEGREDO, escrita em caixa alta, discorre sobre a ação desempenhada por Ronald McDonald. Se a ação desempenhada solicita ficar em silêncio, há um diálogo direto com a palavra escolhida para centralizar a manchete. Quanto ao subtítulo, também se encontra uma confluência com o participante representado. Percebe-se, portanto, que o personagem da McDonald's não está ali aleatoriamente, mas para construir um sentido. Ao ler o subtítulo, o interlocutor (ou participante interativo) identifica a temática da matéria que estará no interior da revista, bem como o porquê da escolha da imagem principal.

A metafunção interativa - o contato, a distância social, a perspectiva e a modalidade - é algo bem representado na edição 154 da revista Mundo Estranho. O contato está presente no vetor entre o participante interativo e o leitor, efetuando-se o que Kress e van Leeuwen (1996) chamam de demanda. A ligação entre o participante Ronald McDonald e o leitor é tão forte que independentemente da posição de ambos, o vetor permanece direcionando o olhar entre um e outro, exigindo uma resposta de sua meta. Nesse caso, o participante interativo é o sujeito do ato e espera do leitor a reação de obediência - e, inclusive, de medo -, uma vez que a figura de palhaço causa temor em muitos indivíduos. Apresentando uma distância social no plano fechado, a imagem propõe uma aproximação direta, o que quer dizer que possuem uma relação íntima, representando, portanto, uma situação que está próxima do contexto social do leitor. Quanto à perspectiva, o ângulo utilizado é o frontal, o que aproxima ainda mais o ator de sua meta, permitindo a identificação das emoções do ser representado e, portanto, tornando compreensiva a intencionalidade de sua representação - nesse caso, a 
relação de poder. Dentro da concepção da modalidade, encontram-se os elementos: cor, contextualização, iluminação e brilho.

$\mathrm{Na}$ capa escolhida, pode-se observar que as cores branco, vermelho e amarelo corroboram a figura escolhida. Com essa caracterização, percebe-se que a escolha buscou aproximar-se da realidade da McDonald's, uma vez que essas são as cores próprias da empresa. A maneira como o participante representado está contextualizado indica sua presença real em frente a uma parede branca, que sugere uma parede de cozinha, da qual infere-se um local limpo, em que os produtos da McDonald's são produzidos. Se bem observada, a imagem salta do papel, representando a realidade do indivíduo. É como se a imagem tivesse vida e se relacionasse com maior proximidade do leitor. Observa-se, ainda, que há um sombreamento atrás de Ronald McDonald, provocado pela focalização luminosa de seu rosto. Portanto, a interação provocada entre a linguagem visual e a verbal é bem evidente e contribui para inferências importantes para a compreensão leitora das capas de revista, o que torna tal gênero significativo para o trabalho em sala de aula.

Por fim, tem-se a metafunção composicional, a qual organiza e combina os elementos visuais da imagem, integrando o que foi discutido até aqui: os elementos representacionais e os interativos. Através dela, investigam-se os componentes não verbais, sua posição e caracterização. Nesse momento, observam-se as partes que compõem o todo, sua presença e significação. Na capa aqui analisada, o posicionamento ocupado pela imagem foi a centralização, cuja saliência utiliza-se de um plano de fundo que realça a imagem central, tendo em vista as cores escolhidas e a sua proporcionalidade. Esse posicionamento é chamado de valor de informação. Com ele, percebe-se se o elemento visual está à direita/à esquerda, no topo/na base ou centro/ margem. Na capa escolhida, encontra-se o valor centralização, tendo em vista a ocupação nucleica do espaço, conotando a sua posição de destaque e, consequentemente, de importância. Sendo também o elemento mais saliente, Ronald McDonald encontra-se em primeiro plano e ocupa praticamente todo o espaço da capa, tornando-o bastante nítido e fortemente enquadrado, dirigindo toda a atenção para a sua presença, tornando sua estruturação conectada entre o que é visto e lido.

Como se pode perceber, a análise, a partir da Gramática do Design Visual, estimula um processo de leitura visual interativa e ampla por meio do seu interlocutor construída a partir dos discursos verbais e não verbais presentes - nesse caso específico, nas capas de revista. Ao integrar os elementos verbais e não verbais, a GDV encaminha o olhar do leitor para uma leitura perceptiva das imagens, as quais dialogam ativamente com o verbal. Embora haja outros elementos para serem analisados na imagem escolhida - a edição 154 da revista Mundo Estranho -, foi possível entrar no mundo da imagem, conhecendo sua estrutura e compreendendo que os elementos ali estão não apenas para “enfeitar", mas para apresentar uma relação lógica e dialógica entre o verbal e o não verbal. À medida que a leitura é feita, interagindo com a imagem e seguindo em direção ao texto escrito, o sentido informacional é percebido em sua completude, lembrando que:

O olhar não depende apenas da habilidade dos órgãos da percepção, mas também dos processos mentais, e que ambos necessitam ajustes, treinamento e experimentação para seu desenvolvimento. As atividades pedagógicas voltadas para essa finalidade dizem respeito à conscientização do ato de ver, de sua complexidade e parcialidade. Dizem respeito também ao aprendizado de uma metodologia de aprimoramento da observação (COSTA, 2013, p. 41).

Destarte, as experiências visuais passam por diversos processos de reflexão e análise. É importante que os alunos possam reconhecer-se enquanto leitores atuantes diante das várias linguagens que o mundo contemporâneo lhes disponibiliza. Para Solé (1998), a leitura é um procedimento de interação entre o leitor e o texto; portanto, com a linguagem presente nos textos multimodais, o leitor poderá dialogar, interagir e efetivar novas aprendizagens. 


\section{Tecnologias Digitais Móveis e seus Aplicativos: possibilidades para o LETRAMENTO VISUAL}

Em tempos de mobilidade digital, os sujeitos interagem constantemente por meio de seus smartphones conectados à internet. Por meio deles, é possível ler, escrever, reescrever, desenhar, trocar ideias, concordar, discordar, enfim, possibilidades infinitas de uso num mundo cada vez mais digital e virtual. Reconhecidos como "telefones inteligentes" ou, inclusive, como "computadores na palma da mão", os smartphones são dispositivos que, ao se conectarem à rede mundial de computadores, potencializam inúmeras práticas sociais, provocando mudanças tanto individuais quanto coletivas.

Com a expansão dos smartphones, portanto, novas contribuições surgem não apenas no espaço social, mas, essencialmente, no educacional, uma vez que a classe docente e a estudantil também fazem uso constante desses artefatos tecnológicos. É notório também que, em práticas cotidianas, a utilização se faz tanto com objetivos pessoais quanto profissionais, já que os usos não estão presentes apenas na informalidade, mas em vários contextos e situações. Para Pereira e Lucena (2018, p. 376), "o smartphone é um dispositivo móvel, convergente e ubíquo acessível a docentes e discentes nos diferentes níveis educacionais e que pode potencializar novas práticas pedagógicas em que o aluno seja protagonista e coautor de conhecimentos e produções em rede".

Desse modo, compreende-se que, nas relações estabelecidas com as pessoas, o conhecimento também se constrói e se ressignifica. Na contemporaneidade, por meio da utilização das tecnologias digitais móveis, podem-se potencializar diferentes práticas educacionais, uma vez que, ao utilizá-las, buscam-se novas formas de ensinar e de aprender, tornando-as significativas, já que, nessa perspectiva, tais dispositivos são utilizados num processo "pelo qual uma nova informação se relaciona com um aspecto relevante da estrutura do conhecimento do indivíduo" (MOREIRA; MASSINI, 2001, p. 17). Ou seja, ao fazer uso desses dispositivos em sala de aula, permitem-se movimentos pedagógicos que contribuem para que os alunos envolvidos interliguem o que já sabem com as novas descobertas. Dessa forma, por meio da utilização desses dispositivos, é possível "facilitar a captação da estrutura conceitual do conteúdo e sua integração à estrutura cognitiva do aluno, tornando o material significativo" (p. 47).

Ao trabalhar com os alunos, a leitura visual, a partir das tecnologias digitais móveis, como proposto a pesquisa aqui apresentada, em que os alunos aprofundaram seus conhecimentos sobre o gênero textual capa de revista, utilizado para leitura, compreensão e produção, tencionaram-se atividades que permitiram comparar temáticas afins, provocar reflexões sobre as imagens dispostas, bem como oportunizar provocações outras, permitindo, assim, que houvesse um diálogo não só externo, mas também interno. Diante dessa dinâmica, os alunos puderam inferir o porquê das escolhas de cada objeto, compreender a ideia de composição e intencionalidade e, por fim, perceber os objetivos destinados aos seus leitores. Desse modo, percebe-se que provocar no aluno um olhar reflexivo diante dos diversos textos que o rodeiam contribui para que cada um construa sua própria visão social da língua, a partir das relações de sentido percebidas pelo seu próprio olhar e não apenas absorvendo um único ponto de vista: o do professor, ideal oriundo da perspectiva educacional expositiva.

Outrossim, da mesma forma que as tecnologias digitais móveis contribuem para o compartilhamento de textos e discussões, por exemplo, tais dispositivos também proporcionam um envolvimento não só visual, mas também producente, uma vez que seus aplicativos permitem uma movimentação ativa, em que cada um decide o caminho a ser percorrido e oportuniza a construção de produtos potencialmente colaborativos e compartilháveis. O PicsArt, aplicativo de (re)produção de imagens utilizado na proposta, e que será detalhado mais adiante, tem uma usabilidade intuitiva que permite um manuseio ativo e fácil, possuindo interfaces que atendem aos interesses dos alunos e à criatividade que cada um possui, tornando o dispositivo atraente e 
capaz de atender às suas expectativas e/ou necessidades. Através desse aplicativo, portanto, é possível construir imagens, recortar, colar, arrastar, enfim, compor uma produção visual que atenda aos interesses e intencionalidade de quem está produzindo, o que dinamiza ainda mais as possibilidades de utilização pedagógica desse recurso. Essa construção se dá tanto individual quanto coletivamente, oportunizando, assim, novos percursos e resultados.

Partindo dessa abordagem, compreende-se que a adoção das tecnologias móveis e de seus aplicativos em práticas pedagógicas permite uma dinâmica de construção e interação que oportunizam leituras dialogadas e, inclusive, experiências práticas com múltiplas possibilidades. A exemplo da pesquisa aqui apresentada, o PicsArt, aplicativo instalado nos smartphones dos alunos, contribuiu significativamente para o alcance dos objetivos traçados, tais como: estimular inferências, compreender a composição multimodal e sua intencionalidade, desenvolver a leitura visual. Nota-se, portanto, que o uso desses instrumentos é uma alternativa para o desenvolvimento de práticas pedagógicas que visem, dentre outras possibilidades, o letramento visual, já que permitem a integração entre as diversas linguagens (verbal, visual e audiovisual), além de possibilitar o envolvimento e a participação dos alunos em práticas e eventos sociais relacionados ao uso e funções sociocomunicativas.

Nessa perspectiva, ao passo que os alunos, ao visualizarem as capas de revista, eram provocados a perceber os elementos explícitos e, posteriormente, a inferir os implícitos, bem como a buscar as razões e motivações para a composição visualizada, depreende-se um envolvimento ativo e reflexivo, em que as possibilidades de compreensão se ampliam, ou seja, provoca-se cognitivamente o aluno para a construção de sua própria concepção diante do que está sendo trabalhado. Isso fora possível especialmente pelos processos que permitiram o diálogo entre aluno-professor/aluno-aluno que, em um movimento de troca de percepções de vida, constroem a sua visão por meio da leitura.

Eu nunca tinha olhado uma capa de revista dessa forma. Achei muito legal. Curioso foi quando $A G^{[5]}$ viu a diferença da palavra 'Segredo' nas duas capas que a senhora mostrou. Eu nem tinha pensado assim. Pra mim era o mesmo sentido porque a palavra era a mesma, mas realmente quando a gente olha para as imagens com mais atenção e olha pra palavra os sentidos são outros. [...] Gostei muito de conhecer cada elemento que está em uma capa (Fala do aluno JL $\mathrm{L}^{[6]}$ ).

Partindo dessa abordagem, compreende-se que o ato de ler é um processo linguístico social e culturalmente constituído e parte de interações em que histórias de vida, contextos de comunicação, expectativas e épocas dialogam entre si. Esse tipo de abordagem pedagógica permite que os alunos vivenciem a própria linguagem e sua funcionalidade. Assim, é possível estabelecer relações entre os conhecimentos anteriormente constituídos e as novas informações, fazer inferências, comparações, formular perguntas e, mais ainda, processando, criticando, contrastando e avaliando as informações que são apresentadas, produzindo sentido para o que se lê. Em outras palavras, "age-se estrategicamente, o que permite dirigir e autorregular o próprio processo de leitura e produção” (KOCH; ELIAS, 2012, p. 18). No tocante a essa dinâmica metodológica, vêse que os professores podem se apropriar das tecnologias digitais de maneira a desenvolver, por meio de sua utilização, novas práticas de leitura (e escrita), as quais devem configurar-se estimulantes, reflexivas, diversificadas, reforçando que, mesmo não tendo sido projetadas para uso educacional, a imersão dos recursos digitais no espaço escolar proporciona outros percursos metodológicos e, consequentemente, a possibilidade de novas aprendizagens.

\footnotetext{
${ }^{5}$ Iniciais do nome do aluno citado, forma escolhida pelos participantes.

${ }^{6}$ Cf. nota 6.
} 
Os dispositivos móveis não foram planejados para o uso educativo, mas podem ser facilmente incorporados nos planejamentos de aula, permitindo a realização de atividades de estudo dentro e/ou fora do momento escolar, com propósito educacional. A inserção dos dispositivos na prática docente torna-se mais uma questão pedagógica do que tecnológica (SONEGO; BEHAR, 2015, p. 532).

É nesse sentido que a presença e a utilização das tecnologias digitais móveis no contexto educacional, que flexibilizam os espaços e expandem a comunicação, são requisitos que podem ser observados por docentes para a construção de novos saberes. Para Araújo e Costa (2009), é preciso propor atividades na perspectiva do ensino produtivo, momento em que o aluno refletirá sobre o fenômeno estudado e, assim, construirá novos, ou seja, promoverá uma aprendizagem significativa na qual um novo conhecimento reconfigura o que o indivíduo já sabe. É necessário, portanto, excluir ações em que o aluno seja levado a realizar exercícios estruturais e mecanizados, uma vez que isso dificulta as modificações cognitivas do indivíduo.

Assim, a linguagem híbrida, tão marcante nas relações sociocomunicativas atuais e promovidas pelo acesso aos aparelhos digitais, traz uma diversidade de recursos linguísticos e extralinguísticos interligados que evidenciam significados importantes na construção de novos letramentos, o que poderá trazer contribuições para a sala de aula.

O aparelho de celular é um suporte que está programado para receber diferentes mídias (vídeo, fotografias, gravações de áudio) como também permite o acesso a outros meios de comunicação (rádio, televisão, internet, etc.). Assim, um celular pode produzir suas próprias mídias - filmar, fotografar, gravar sons - como também distribuí-las em diferentes meios de comunicação e assim provocar interatividade (BARRAL, 2012, p. 98).

Nessa perspectiva, a realidade está cada vez mais presente, visto que, por meio das tecnologias digitais móveis, todo e qualquer indivíduo insere-se num mundo multimodal e produtor, permitindo, assim, adentrar em algo que "requer dos seus interlocutores competências linguísticas outras para produzir e ler textos" (AQUINO; SOUZA, 2008, p. 33). Conhecê-las e reconhecê-las é, portanto, compreender sua representatividade e seus efeitos de sentido. No tocante ao trabalho desenvolvido em sala de aula, os alunos foram capazes de considerar que a presença das linguagens verbal e não verbal é marcante e que a imagem principal, quando direciona o olhar para o leitor, prende a sua atenção e, inclusive, é a primeira a ser olhada em uma capa de revista, cujo objetivo é atrair o leitor. Essa percepção foi construída à medida que os alunos se envolviam com a atividade proposta, observando e manuseando os materiais utilizados e o percurso escolhido para promover o letramento visual, consolidando-se ao produzir a sua própria capa de revista com base nos conhecimentos adquiridos.

Para Souza (2009), levar o aluno a analisar e produzir eventos comunicativos, "identificando suas características temáticas, estruturais ou estilísticas e relacionando-os às esferas de atividade social, à audiência, às condições de produção, dentre outras relações que podem ser estabelecidas” (p. 203) implica um novo olhar sobre o ensino e a aprendizagem.

Portanto, do ponto de vista pedagógico, é preciso compreender não só que "a imagem desperta emoções e promove reações, impactando o observador” (COSTA, 2013, p. 37), mas também por que isso acontece e como se efetiva. Costa pontua como o visual reflete e que, "apesar do imediatismo e da espontaneidade da imagem visual, é a cultura que possibilita uma interpretação mais profunda e apurada da experiência visual". E, ainda, a autora, percebendo o potencial da cultura visual, lança alguns questionamentos pertinentes quanto à utilização das imagens em contextos educacionais.

Se a leitura de imagens é tão importante para a cultura humana, se ela se apresenta de forma tão espontânea que nem mesmo nos damos conta de estarmos desenvolvendo uma importante atividade cognitiva, se ela é universal e aproxima as culturas, por que a educação formal procura excluir a linguagem visual das atividades 
pedagógicas tão logo a criança se mostre medianamente alfabetizada? Por que a imagem se torna um elemento secundário na educação à medida que o aluno se alfabetiza? (COSTA, 2013, p. 36).

Isto leva à visão multifuncional das escolhas linguísticas verbais e visuais, bem como permite compreender os modos como a linguagem é utilizada para o atendimento de diferentes propósitos e para a funcionalidade em diferentes contextos. Desse modo, compreende-se que as linguagens múltiplas oriundas principalmente das relações sociais, ou seja, do envolvimento com o outro, são criadas a partir das vivências que buscam alcançar determinados objetivos. Sendo assim, trabalhar as linguagens tanto verbal quanto não verbal nas práticas em sala de aula, contribui para que os sujeitos compreendam a flexibilidade da língua, tanto no seu formato quanto na sua funcionalidade.

Nesse contexto, pode-se encontrar, nas tecnologias digitais, recursos não só dinamizadores das práticas educativas, ou melhor, não apenas na ideia de motivação dos alunos para participarem da aula, mas nos novos modos de fazer educação e, consequentemente, em novas formas de promover saberes. Assim, observando que o mundo virtual é permeado por múltiplas linguagens, utilizar-se de seus instrumentos é oportunizar não só processos, mas aprendizagens significativas, tendo em vista a provocação cognitiva e os movimentos proporcionados pelos dispositivos, os quais agem enquanto porta de entrada para vários caminhos.

as tecnologias móveis podem ser utilizadas como um catalisador de uma mudança no paradigma educacional, que promovam a aprendizagem ao invés do ensino, que insiram o controle do processo de aprendizagem nas mãos dos alunos (OLIVEIRA; MERCADO, 2016, p. 211).

A priori, o docente, ao sentir a necessidade de trabalhar a linguagem multimodal, fazendo uso das tecnologias digitais móveis, necessita perpassar pela escolha de aplicativos que se adequem ao que se pretende alcançar. Sendo assim, a escolha do PicsArt, presente nesta proposta, não foi aleatória nem, muito menos, com o propósito de simplesmente utilizarem seus smartphones e construírem imagens. Essa escolha fez parte de uma dinâmica pedagógica envolvendo leitura, autoria, colaboração e compartilhamento, ações conectadas para que os alunos compreendessem a construção de sentido multimodal, promovendo, portanto, práticas de letramento visual a partir dos dispositivos móveis tão presentes na vida dos próprios alunos.

\section{O Aplicativo PicsArt em Práticas Educativas}

O PicsArt é um aplicativo que pode ser baixado gratuitamente em dispositivos móveis ${ }^{7}$ e que tem como principal função a edição de imagens com vários propósitos, seja para (re)construir, seja para corrigir falhas. Esse aplicativo está disponível para Android, Windows Phone e IOS, o que contribui para que possa ser utilizado em qualquer dispositivo móvel, basta ter acesso à internet e, no mínimo, $111 \mathrm{MB}$ de memória. A questão da memória é uma das preocupações atuais quando se pretende utilizar aplicativos em sala de aula, pois, muitas vezes, os alunos possuem smartphones que não apresentam disponibilidade de espaço suficiente, não por terem excesso de aplicativos instalados pelos alunos, mas por aplicativos que já vêm instalados de fábrica e sem permissão para desinstalação, o que compromete a inclusão de novos apps em seus dispositivos e, consequentemente, impossibilita o desenvolvimento de algumas propostas. A preocupação com essa realidade intensificou ainda mais a necessidade de conhecer a realidade da escola e, também, da turma envolvida, processo indispensável para o planejamento e desenvolvimento da proposta.

Assim como em várias escolas da rede pública no Brasil, a escola onde a pesquisa foi desenvolvida não possuía dispositivos móveis para utilização com os alunos em sala de aula. Havia apenas um notebook

\footnotetext{
7 Disponível em: https://picsart.com/.
} 
disponível para uso dos professores em suas aulas com o datashow, porém esse recurso não seria suficiente para o envolvimento ativo dos alunos. Além disso, embora a rede wi-fi estivesse disponível, nem sempre funcionava, devido à oscilação na conexão, representando outra problemática. Com base nessa realidade da escola, foi feito o levantamento com os alunos para saber quais possuíam smartphone, como estava a situação de armazenamento e se possuíam acesso à internet, pois, a partir de sua realidade, seria possível planejar melhor. Nesse processo, chegou-se ao resultado apresentado no Quadro 1:

Quadro 1 - Levantamento junto aos alunos sobre os dispositivos móveis

\begin{tabular}{|c|c|c|c|}
\hline $\begin{array}{l}\mathbf{N}^{\circ} \text { de alunos } \\
\text { participantes da proposta }\end{array}$ & $\begin{array}{l}\mathbf{N}^{\text {o de alunos com }} \\
\text { smartphones }\end{array}$ & $\begin{array}{c}\mathbf{N}^{\circ} \text { de alunos com acesso à } \\
\text { internet }\end{array}$ & $\begin{array}{l}\mathrm{N}^{\mathbf{o}} \text { de alunos com memória } \\
\text { disponível no smartphone } \\
\text { para instalação do PicsArt }\end{array}$ \\
\hline 38 & 32 & 27 & 27 \\
\hline
\end{tabular}

Fonte: Elaborado pelos autores.

Como se pode observar no Quadro 1, nem todos os 38 alunos participantes possuíam celular e o acesso à internet era ainda menor, apenas 27. Em contrapartida, esses 27 alunos apresentaram todos os prérequisitos necessários para o desenvolvimento da proposta, uma vez que tanto havia espaço no dispositivo para baixar o novo aplicativo, como também tinham acesso à internet, seja através dos dados móveis, seja pela wi-fi de casa ou em outros espaços. Os modos de acesso à internet não foram computados discriminadamente, já que a caracterização do tipo de acesso à rede mundial de computadores não interferiria no desenvolvimento da proposta.

Por outro lado, embora houvesse a preocupação com os pré-requisitos do dispositivo móvel envolvido no trabalho - cuja razão não estava relacionada à complexidade do aplicativo, mas a questões de infraestrutura -, com o levantamento percebeu-se que seria possível o desenvolvimento da proposta, mas com alguns ajustes, já que nem todos possuíam o dispositivo. Diante dessa problemática, os próprios alunos sugeriram sua realização em dupla. Outra sugestão feita, e acatada, foi que eles baixassem antecipadamente em casa algumas imagens que pudessem ser utilizadas em suas capas. Esse diálogo foi de grande importância, pois percebe-se que os alunos se conectaram com a proposta e se mobilizaram para que o desenvolvimento se desse sem contratempos. Infere-se, com isso, que estabelecer diálogos, permitir negociações, escolhas e sugestões constituem uma metodologia que torna as práticas de sala de aula não só mais envolventes, mas também potencializadoras de aprendizagens plurais. $\mathrm{O}$ fato de a produção não acontecer de forma individual, não dificultou nem impediu a sua realização, mas, sim, oportunizou a criação de um produto a partir de mais de uma voz, fazendo emergir a cooperação e a colaboração entre eles.

O próximo passo foi organizar as duplas e apresentar o app PicsArt, compreendendo a sua funcionalidade e as possibilidades de utilização. A escolha desse aplicativo se deu também na interação com os alunos. Primeiramente, foi feita uma pesquisa na rede sobre aplicativos que promovessem a produção de imagens e que possuíssem uma boa aceitação de seus usuários, situação que está diretamente relacionada à facilidade de manuseio e ao atendimento aos interesses, além do atendimento aos objetivos do conteúdo da disciplina. Após esse levantamento, foram apresentados aos alunos cinco aplicativos. Com isso, eles próprios puderam opinar qual o melhor para o trabalho a ser desenvolvido, estabelecendo, assim, um processo de negociação, prática importante no contexto da sala de aula, uma vez que não só promove a conexão dos alunos com a proposta docente, mas os coloca em um movimento ativo de diálogo e de construção coletiva e colaborativa.

Nesse momento, um dos alunos destacou a facilidade de uso do PicsArt e que, por já conhecer e usar em seu cotidiano, poderia também ajudar a quem tivesse dificuldade de realizar a tarefa. Com base na discussão 
coletiva, reforça-se que o PicsArt foi escolhido não apenas pela interface simples, mas também por percebê-lo um recurso digital que permite a utilização de forma pedagógica, envolvendo a multimodalidade e seus sentidos, tendo em vista a possibilidade que o usuário tem de percorrer uma série de funcionalidades, por meio das ferramentas diversificadas e disponíveis em sua interface. A partir do uso do aplicativo, portanto, o praticante cultural é convidado a tomar suas próprias decisões, promovendo autonomia do indivíduo e o estimulando à construção do novo, configurando sua importância no contexto educacional.

Diante dessa possibilidade, o estudo aqui apresentado e discutido seguiu com o propósito de trabalhar a multimodalidade, especialmente quanto à linguagem visual e suas relações com os demais elementos linguísticos, a partir do gênero textual capa de revista, gênero trabalhado nas aulas de Língua Portuguesa, conforme o currículo da disciplina. Entendida como a composição que apresenta mais de um modo de representação, a multimodalidade é algo que há muito existe, uma vez que, em qualquer situação comunicativa, utiliza-se mais de um elemento semiótico, seja ele verbal ou não verbal, embora tenha se destacado na contemporaneidade, tendo em vista a presença ativa das tecnologias digitais. Para Dionísio (2011, p. 139),

Se as ações sociais são fenômenos multimodais, consequentemente, os gêneros textuais falados e escritos são também multimodais porque, quando falamos ou escrevemos um texto, estamos usando no mínimo dois modos de representação: palavras e gestos, palavras e entonações, palavras e imagens, palavra e tipografia, palavras e sorrisos, palavras e animações etc.

De acordo com Bamford (2009), compreende-se que, quando se desenvolve um trabalho envolvendo a linguagem visual, é possível desenvolver a capacidade leitora dos alunos diante da multimodalidade linguística. Nesse contexto, a autora afirma que, para alcançar esse letramento visual na educação, é preciso:

- desenvolver o pensamento crítico dos alunos em relação às imagens;

- melhorar as habilidades orais e escritas a partir da leitura de imagens;

- introdução à produção de imagens por meio de técnicas e software;

- integrar o letramento visual de uma forma transversal para todas as áreas do currículo;

- garantir equilíbrio entre o visual e o textual na sala de aula;

- conhecer os princípios do letramento visual;

- provocar os alunos para que criem hipóteses sobre os sentidos das imagens;

- incentivar os alunos a investigar criticamente, analisar e avaliar os valores contidos nas imagens (p. 5).

Nesse ponto, Bamford chama a atenção para o desenvolvimento de leitores críticos diante da linguagem multimodal, tendo em vista tratar-se de uma manifestação discursiva cujos elementos trazem informações significativas e, portanto, possíveis de serem analisadas e compreendidas. O entrelaçamento entre as escolhas linguísticas verbais e visuais são efetivadas com vistas a atender a diferentes contextos e propósitos, o que tem gerado, principalmente no universo digital contemporâneo, a caracterização de novas identidades sociais, chamando atenção para a necessidade de uma leitura crítica e compreensiva.

$\mathrm{Na}$ mesma discussão, Kress e van Leeuwen (1996) pontuam o letramento visual por meio de práticas em sala de aula que desenvolvam com os alunos suas capacidades de análise crítica das múltiplas linguagens. Com a leitura imagética, portanto, aprende-se a integrar os códigos semióticos dos enunciados contemporâneos, por exemplo, compreendendo seus modos, meios e práticas comunicativas e discursivas. Assim, com base em Bamford (2009) e Kress e van Leeuwen (1996), é possível sintetizar algumas operações cognitivas importantes para o processo de letramento visual, como pode ser observado na ilustração a seguir: 


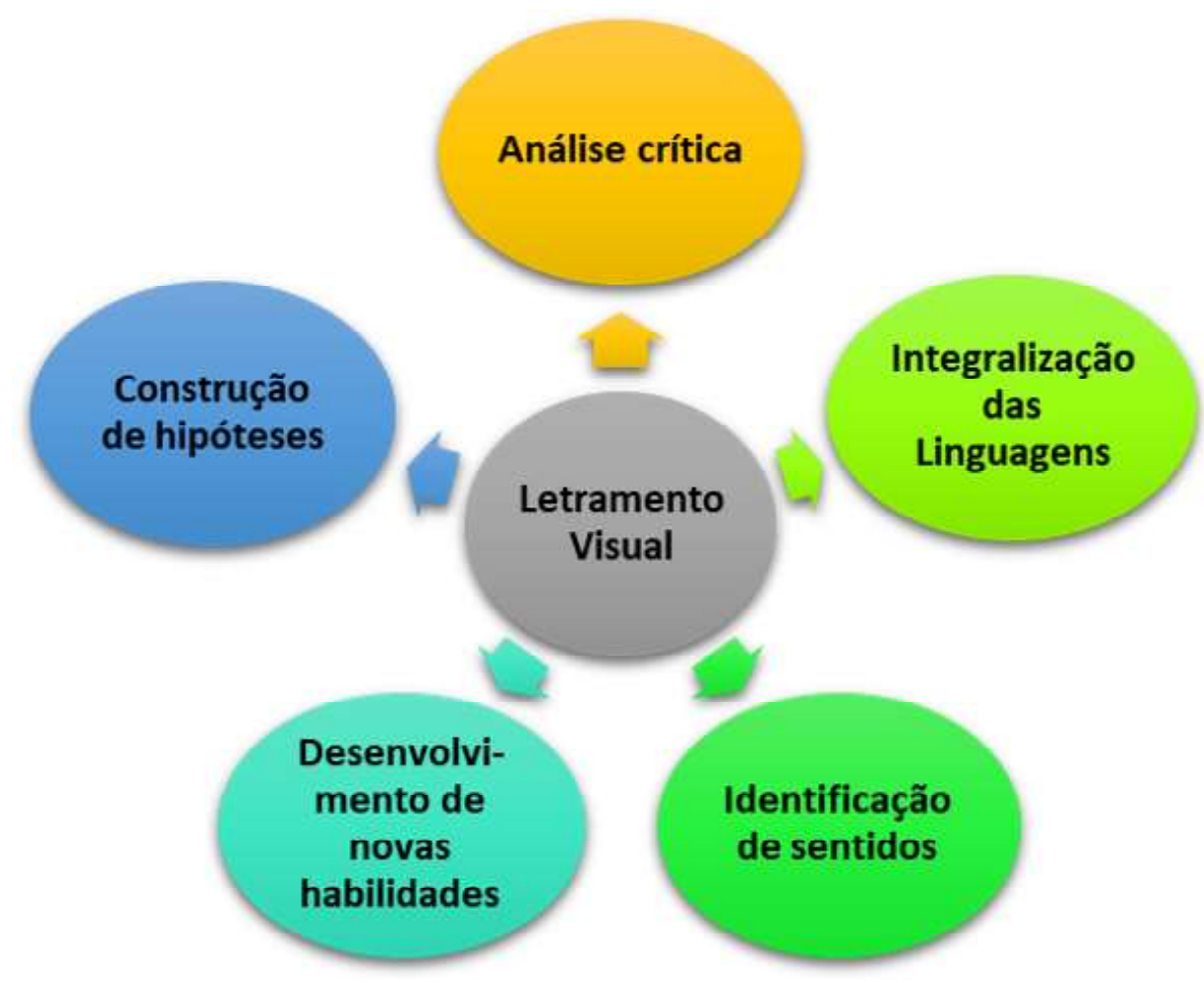

Fonte: Elaborada pelos autores.

Figura 2 - Operações cognitivas para o letramento visual

Ao desenvolver o letramento visual junto aos alunos, as operações cognitivas ilustradas na Figura 2 constituem um processo que envolve um movimento direcionado a múltiplas habilidades, as quais podem (e devem) ser potencializadas pelas provocações e direcionamentos dos professores durante as suas práticas de sala de aula. Ler imagens, relacioná-las ao contexto social e linguístico requer uma postura crítica capaz de proporcionar compreensões de seus sentidos explícitos e implícitos. Assim, o ato de ler passa a exigir outras habilidades do leitor, já que a multimodalidade linguística faz parte da composição do texto escrito para além da ilustração. Dionísio (2005) sugeriu o termo multiletramentos para designar a capacidade de atribuir e produzir sentidos a mensagens multimodais. Na concepção da autora, uma pessoa letrada deve ser uma pessoa "capaz de atribuir sentidos a mensagens oriundas de múltiplas fontes de linguagem" (2005, p. 131). Ainda para a autora, "aspectos verbais e pictoriais se completam de tal forma que a ausência de um deles mesmo sendo o de menor incidência, afeta a unidade do texto" (2005, p. 134). Dessa forma, palavras e imagens não devem ser lidas isoladamente, uma vez que tais semioses se inter-relacionam na construção dos sentidos, o que coloca a prática do letramento visual como algo indispensável na sociedade contemporânea.

Desse modo, compreendendo a capa enquanto gênero permeado por múltiplas linguagens cuja composição está conectada em si para produzir sentidos, a proposta desenvolvida junto ao $8^{\circ}$ ano em uma escola pública do município de Tobias Barreto, SE, buscou promover leituras de capas diversificadas, apresentando como se dá tal composição e o porquê das escolhas visuais, tendo como produto final a elaboração de capas de revistas fictícias, criadas pelos próprios alunos, utilizando, para isso, o aplicativo PicsArt. Apesar de a proposta utilizar-se de outros objetos de aprendizagem como revistas, slides, animação, $\mathrm{ODA}^{8}$ (Objetos

\footnotetext{
${ }^{8}$ Para Tarouco (2003), os objetos educacionais digitais são qualquer recurso, suplementar ao processo de aprendizagem, que pode ser reusado para apoiar a aprendizagem. O termo objeto educacional (learning object) geralmente aplica-se a materiais educacionais projetados e construídos em pequenos conjuntos com vista a maximizar as situações de aprendizagem onde o recurso pode ser utilizado.
} 
Digitais de Aprendizagem), vídeos, atividades impressas e virtuais, essa análise se deterá na produção autoral e colaborativa em que os alunos foram envolvidos a partir do app PicsArt.

Nesse sentido, após o percurso de reconhecimento da composição multimodal das capas de revistas e compreendendo seus elementos estruturais e sua funcionalidade, os alunos foram convidados a produzir as suas próprias capas, criando uma situação hipotética, não se esquecendo de que as escolhas deveriam atender ao público a que se destinaria a revista. Essa etapa da proposta, isto é, da produção da capa, foi desenvolvida em duas aulas de Língua Portuguesa, momento em que os alunos levaram os smartphones para a aula.

Esquematizada a aula de produção das capas de revista dos alunos e, posteriormente, colocada em execução, foram construídas 19 capas. Ao término, as duplas puderam apresentar seu produto final, bem como explicar os sentidos atribuídos por eles no momento da composição, enfatizando a necessidade de, antes de produzir, pensar no seu público-alvo e, assim, gerar interesse pela leitura da revista. Nesse contexto, é importante sinalizar que as quatro capas que serão aqui apresentadas são apenas uma representação das produções dos alunos, já que não havia como abordar todas nesta análise. Vale destacar, ainda, que o critério para a seleção dessas capas foi pelo envolvimento das duplas, pelo atendimento à proposta e pela explanação dos sentidos construídos. Nessa etapa, cada aluno teve a possibilidade de, com o outro, interagir, refletir e escolher os textos e recursos simbólicos não verbais que lhe interessaram, como se pode observar nas capas selecionadas a seguir, as quais são indicadas como D1, D2, D3 e D4, correspondentes às duplas 1, 2, 3 e 4:



Fonte: Elaborada por D1.

Figura 3 - Capa produzida pela D1

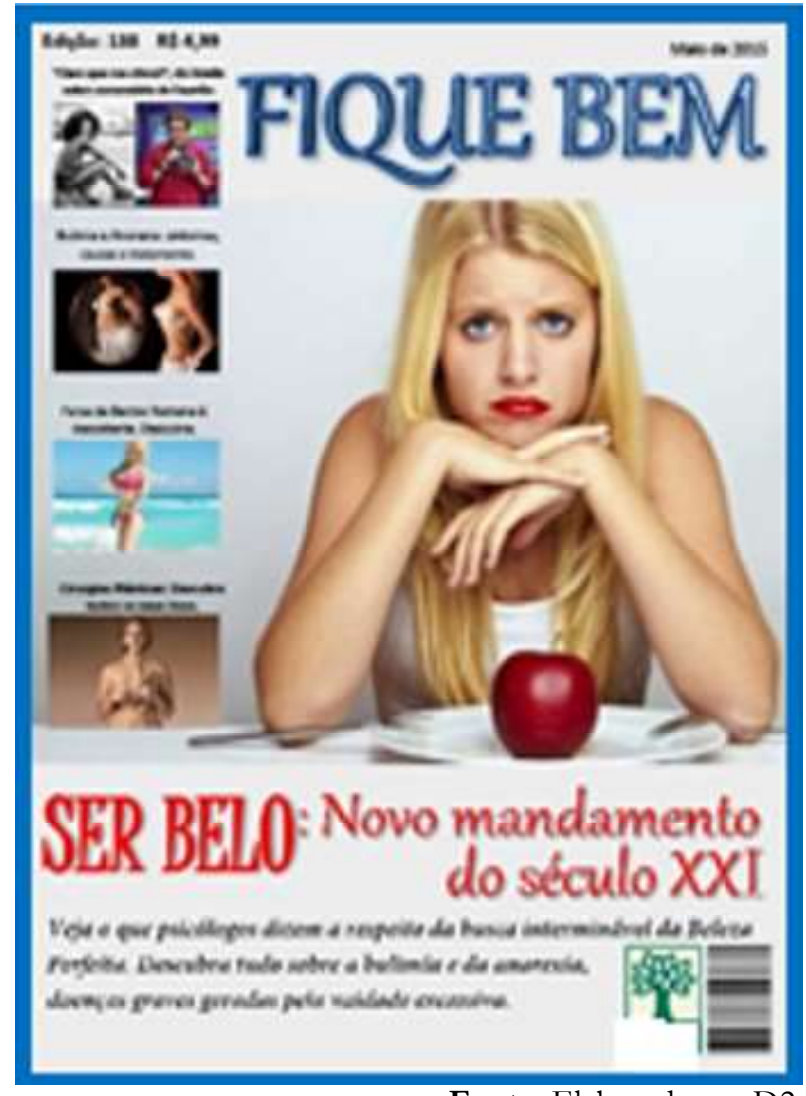

Fonte: Elaborada por D2.

Figura 4 - Capa produzida pela D2 


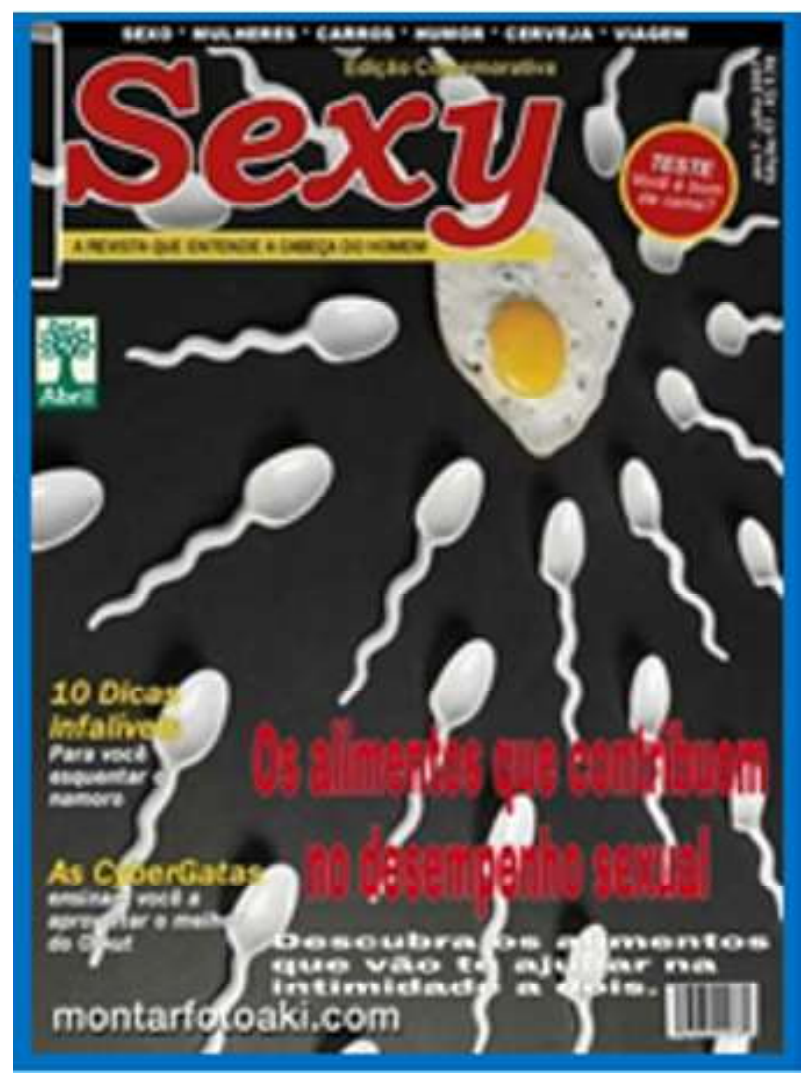

Fonte: Elaborada por D3.

Figura 5 - Capa produzida pela D3

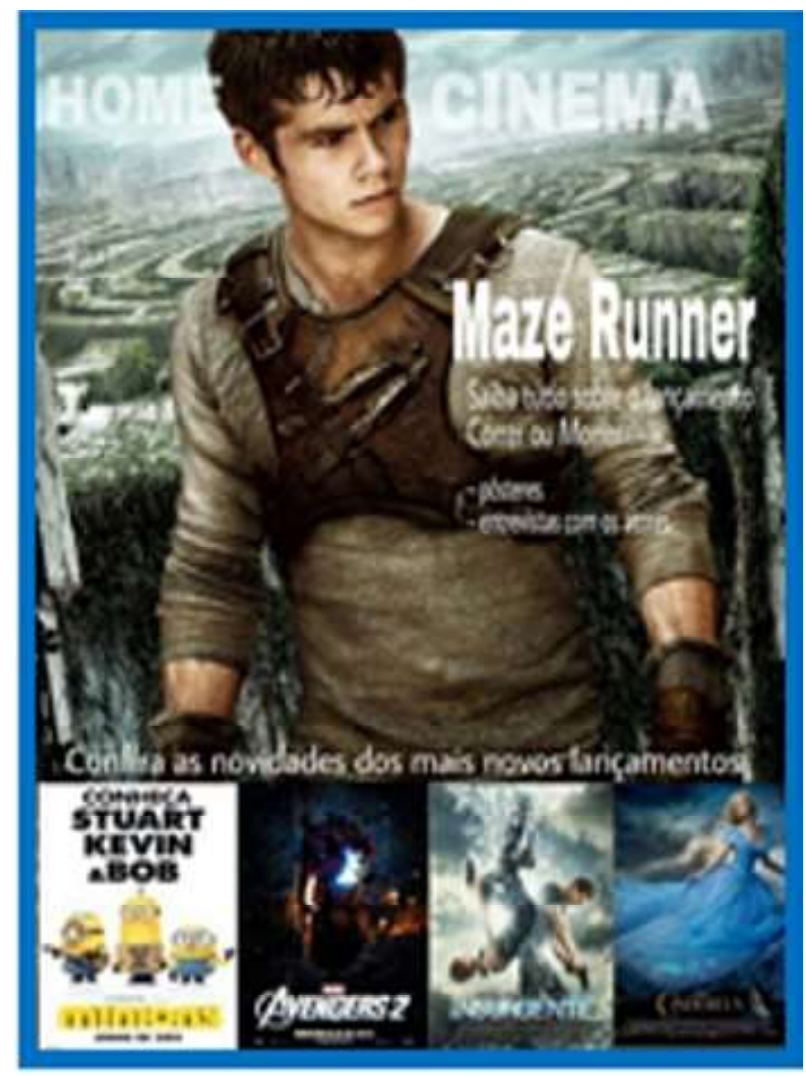

Fonte: Elaborada por D4. Figura 6 - Capa produzida pela D4

Como se pode observar, as Figuras 3 e 4 focalizaram a questão do look, da preocupação com a beleza e o cuidado com o próprio corpo, pertinente para as duplas envolvidas, tendo em vista sua composição feminina. Essa conclusão foi apontada pelas próprias alunas no momento em que houve o diálogo sobre sua produção. Assim, as escolhas que compuseram as capas das duplas 3 e 4 demarcaram o olhar da mulher, demonstrando que o público feminino busca, nas revistas, temas alusivos à beleza, tanto na ideia de estética como também na de saúde.

A gente escolheu essa imagem porque dieta é uma palavra que nós mulheres sempre dizemos, mas que ninguém fica feliz. com ela, apesar de saber que é pro nosso bem, não é só questão de estética, mas de saúde. Daí pensamos em abordar isso na capa da nossa revista (D2).

$\mathrm{Na}$ fala da D2, observa-se que a escolha se deu devido ao universo feminino ter a dieta como algo muito presente. Em contrapartida, tem-se a dieta, a partir do olhar das alunas, com uma carga negativa, reforçada pelo contraste entre o título principal - FIQUE BEM - e a imagem centralizada, uma vez que a figura em saliência não demonstra felicidade. Essa escolha traz à tona os conflitos vividos pela mulher e trazidos pela necessidade da dieta, tão presente em suas vidas.

$\mathrm{Na}$ mesma linha de reflexão, as Figuras 5 e 6 trazem a curiosidade sobre temas relacionados à sexualidade e ao cinema. Nessa produção, fica em evidência que tais temas circulam costumeiramente e explicitamente no universo dos meninos, especialmente na idade em que se encontram. Ressalta-se que essa inferência se dá a partir da realidade vivenciada em sala e presente na fala dos próprios alunos, porém não reflete a visão universal de todos os garotos e todas as garotas, representando o ponto de vista dos participantes. Outrossim, destaca-se também a dinâmica que cada dupla utilizou para compor as imagens, demonstrando familiaridade não só com o PicsArt, mas também com a linguagem multimodal que o gênero textual trabalhado 
apresenta, bem como no objetivo deste gênero, que é atrair a atenção dos leitores, característica marcante para a composição das capas de revista. Em suas capas, fica clara a relação entre a manchete e a imagem central, destacando o principal conteúdo da revista, bem como sua funcionalidade e o público-alvo. É possível perceber, também, composições diversificadas que, contudo, apresentam uma relação de semelhança temática: todas configuram temas direcionados ao público jovem: beleza, sensualidade, moda, cinema e namoro, que foram escolhidos pelos alunos, de acordo com os seus interesses. Assim, a temática escolhida e a composição produzida pelos alunos representam uma compreensão significativa sobre o gênero estudado.

Nesse cenário, ao se utilizarem do app PicArts, os alunos serviram-se dos recursos multimodais presentes e ressaltaram, por exemplo, o que a própria sociedade impõe às mulheres: moda, de um lado, e sofrimento, do outro. Além disso, as cores escolhidas corroboraram os sentidos visuais, inclusive com os comportamentos sociais e culturais, uma vez que as meninas escolheram os tons de cores mais claras e os meninos, os mais escuros. Percebe-se, assim, que os alunos, ao participarem de todos os encaminhamentos da proposta, foram capazes de perceber que a presença das linguagens verbal e não verbal é marcante. Ao perceberem que a imagem principal, quando direciona o olhar para o leitor, prende a sua atenção e, inclusive, é a primeira a ser olhada em uma capa de revista, compreenderam o porquê de determinados textos multimodais estimularem a sua leitura, e outros não. Em síntese, a produção das capas de revista feitas pelos alunos, por meio do PicsArt, demonstra aprendizagens em relação à linguagem visual, uma vez que sua composição demarca a presença de compreensões linguísticas que nortearam as escolhas para seu produto final.

Para Mendonça e Cavalcante (2006), os gêneros textuais na escola devem ser lidos, analisados e produzidos, tendo o cuidado para propor uma organização didática que garanta a integração dos diferentes eixos de língua (leitura, produção e análise linguística) e o envolvimento dos alunos em situações comunicativas reais. Assim, com a realização desse estudo, é possível perceber o alcance dos objetivos propostos tanto no contexto da pesquisa quanto no da disciplina de Língua Portuguesa, haja vista ter conseguido "proporcionar uma aprendizagem colaborativa e cooperativa, incentivar a investigação e o pensamento crítico, oferecer atividades para estimular uma área cognitiva de nível mais elevado exigindo reflexão, análise, síntese e avaliação" (ABAR; BARBOSA, 2008, p. 13).

Daí a importância da participação do aluno enquanto produtor, pois o coloca na condição de autor do seu próprio conhecimento, o que é potencializado pelos dispositivos tecnológicos, uma vez que "os diferentes recursos oferecidos pelas novas tecnologias digitais têm não só viabilizado, mas principalmente incentivado propostas de ensino menos centradas no professor e mais voltadas para a interação e o diálogo" (BRAGA, 2009, p. 184). Nessa perspectiva, o caminho percorrido na busca por desenvolver a competência leitora dos alunos diante dos elementos multimodais que compõem a capa de revista, gênero textual em estudo, oportunizou um envolvimento direto do aluno com as linguagens verbal e não verbal, contribuindo significativamente para a efetivação de aprendizagens, materializadas nas atividades/discussões e na produção final dos alunos. Além disso, as provocações também foram importantes para este processo, já que possibilitou a construção das próprias concepções dos alunos diante do gênero, em um movimento investigativo e de colaboração, tendo em vista que definições e/ou caracterizações não foram apresentadas aos alunos, mas, sim, instigadas ao entendimento e à compreensão em conjunto, potencializadas pelo uso do app PicArts.

\section{ConsideraÇões FinAIS}

As Tecnologias Digitais Móveis, em especial os smartphones, a partir de seus aplicativos, promovem a interação não só entre os alunos, mas também entre eles e o conteúdo trabalhado, contribuindo, desse modo, para as aprendizagens significativas. Isso se dá por possibilitarem práticas de ensino e de aprendizagem não abstratas, uma vez que o aluno não apenas ouve ou vê, mas se relaciona diretamente com os conceitos. 
Com o uso do app PicsArt, portanto, evidenciou-se o desenvolvimento da leitura visual, levando o aluno a compreender o processo que envolve a multimodalidade linguística presente em capas de revista e que essa composição atende a um objetivo: atrair o leitor. Esse entendimento foi percebido a partir do envolvimento dos alunos desde o primeiro contato com o gênero trabalhado, o conhecimento dos elementos que o compõem e as razões da sua composição. No percurso, os alunos, ao questionarem ou se posicionarem, exemplificaram modos de aprender ativos, tão necessários para que a aprendizagem aconteça de modo eficaz e consistente, uma vez que se consegue promover mudanças cognitivas e coletivas indispensáveis no processo educacional.

No entanto, é importante reafirmar os desafios suscitados tanto quanto à falta de internet na escola ou a sua conexão limitada, quanto à configuração dos smartphones dos alunos, já que são situações que muitas vezes dificultam o desenvolvimento de atividades que buscam fazer uso dos dispositivos móveis. Além disso, é importante reafirmar que fazer uso das tecnologias móveis digitais em espaços e objetivos educacionais não se trata simplesmente de saber manuseá-las. O desafio está na apropriação de sua funcionalidade, de seus alcances e de seus limites. Assim, percebe-se que é especialmente nesse quesito que muito ainda pode ser feito, evidenciando a necessidade de formação docente para a apropriação de práticas pedagógicas que, de fato, potencializem o ensino e, assim, consolidem as aprendizagens.

Desse modo, entende-se que a experiência aqui analisada, ao envolver-se com a leitura da multimodalidade, contribuiu para que o aluno desenvolvesse um olhar crítico perante os elementos visuais que compõem o gênero textual trabalhado, tendo em vista não só a seleção das imagens que fizeram uso, mas nos diálogos existentes nas discussões e na organização do seu produto, capacitando-o para novos olhares diante das linguagens que constituem a composição textual. Além disso, possibilitou um trabalho diferenciado nas aulas de Língua Portuguesa, as quais se utilizaram da tecnologia como recurso didático-pedagógico capaz de produzir aprendizagens.

\section{REFERÊNCIAS}

ABAR, C. A. A. P.; BARBOSA, L. M. Webquest: um desafio para o professor. São Paulo: Avercamp, 2008.

AQUINO, L. D. de; SOUZA, M. A multimodalidade no gênero blog. In: ALMEIDA, D. B. L. de (org.). Perspectivas em análise visual: do fotojornalismo ao blog. João Pessoa: Editora da UFPB, 2008. p. 33-43.

ARAÚJO, J. C.; COSTA, N. Momentos interativos de um chat aberto: a composição do gênero. In: ARAÚJO, J. C. (org.). Internet \& ensino: novos gêneros, outros desafios. Rio de Janeiro: Singular, 2009. p. 21-34.

BAMFORD, A. The visual literacy white paper. Disponível em: https://bit.ly/39YYXu3. Acesso em: 10 abr. 2015.

BARRAL, G. L. L. Liga esse celular! Pesquisa e produção audiovisual em sala de aula. Revista Fórum Identidades, Itabaiana: GEPIADDE, a. 6, v. 12, p. 94-117, jul./dez. 2012.

BRAGA, D. B. Práticas letradas digitais: considerações sobre possibilidades de ensino e de reflexão social crítica. In: ARAÚJO, J. C. (org.). Internet \& ensino: novos gêneros, outros desafios. Rio de Janeiro: Singular, 2009. p. 181-195.

COSTA, C. Educação, imagem e mídias. São Paulo: Cortez, 2013. 
DIONISIO, A. P. Gêneros multimodais e multiletramento. In: KARWOSKI, A. M.; GAYDECZAKA, B.; BRITO, K. S. Gêneros textuais: reflexões e ensino. Palmas; União da Vitória, PR: Kaygangue, 2005. p. 159177.

DIONISIO, A. P. Gêneros textuais e multimodalidade. In: KARWOSKI, A. M.; GAYDECZKA, B.; BRITO, K. S. Gêneros textuais: reflexões e ensino. 4. ed. São Paulo: Parábola, 2011. p. 135-151.

FERNANDES, J. D. C.; ALMEIDA, B. L. de A. Revisando a Gramática Visual nos cartazes de guerra. In: ALMEIDA, D. B. L. de (org.). Perspectivas em análise visual: do fotojornalismo ao blog. João Pessoa: Editora da UFPB, 2008. p. 9-31.

GIL, A. C. Métodos e técnicas de pesquisa social. 5. ed. São Paulo: Atlas, 1999.

KOCH, I. V.; ELIAS, V. M. Ler e compreender os sentidos do texto. 3. ed. São Paulo: Contexto, 2012.

KRESS, G; VAN LEEUWEN, T. Reading images: the grammar of visual design. London: Routledge, 1996.

MENDONÇA, M.; CAVALCANTE, M. C. B. O trabalho com gêneros por meio de projeto. In: SANTOS, C. F.; MENDONÇA, M.; CAVALCANTE, M. C. B. Diversidade textual - os gêneros na sala de aula. Belo Horizonte: Autêntica, 2006. p. 115-132.

MOREIRA, M. A.; MASINI, E. A. F. S. Aprendiragem significativa: a teoria de David Ausubel. São Paulo: Centauro, 2001.

MUNDO Estranho, Editora Abril, São Paulo, ed. 154, jul. 2014.

OLIVEIRA, C. A.; MERCADO, L. P. L. Ensino de matemática: utilizando o aplicativo QR Code no contexto das tecnologias móveis. In: COUTO, E.; PORTO, C.; SANTOS, E. App-Learning: experiências de pesquisa e formação. Salvador: EDUFBA, 2016. p. 211-226.

OTTONI, M. A. R.; LIMA, M. C. Discursos, identidades e letramentos. São Paulo: Cortez, 2014.

OUVERNEY, J. R. A mulher retrata em comerciais de cerveja: venda de mulheres ou de bebida? In: In: ALMEIDA, D. B. L. de (org.). Perspectivas em análise visual: do fotojornalismo ao blog. João Pessoa: Editora da UFPB, 2008. p. 45-62.

PEREIRA, J. T. L.; LUCENA, S. A produção de memes com smartphone: outras formas de aprender na educação básica. In: SANTOS, E.; PORTO, C. (org.). App-education: fundamentos, contextos e práticas educativas luso-brasileiras na cibercultura. Salvador: EDUFBA, 2019. p. 371-388.

SANTOS, S. V. de C. A. Competência motora dos textos multimodais: interagindo com objetos digitais de aprendizagem. 2015. Dissertação (Mestrado em Letras Profissional em Rede) - Universidade Federal de Sergipe, Itabaiana, 2015. Disponível em: https://bit.ly/3pn8Mc5.

SOLÉ, I. Estratégias de leitura. Porto Alegre: Artmed, 1998.

SONEGO, A. H.; BEHAR, P. M-learning: reflexões e perspectivas com o uso de aplicativo educacionais. In: SANCHEZ, J. (ed.) Nuevas ideas en Informática Educativa TISE 2015. Santiago: Universidad do Chile, 2015. p. 521-526. 
SOUZA, S. C. T. de. As formas de interação na internet e suas implicações para o ensino de língua materna. In: ARAÚJO, J. C. (org.). Internet \& ensino: novos gêneros, outros desafios. Rio de Janeiro: Singular, 2009. p. 196-204.

SPENGLER, M. L. P. Leitura no livro de imagem: um passeio de "ida e volta" pelo livro de Juarez Machado. 2010. Dissertação (Mestrado em Ciências da Linguagem) - Universidade do Sul de Santa Catarina, Tubarão, 2010.

TAROUCO, L. M. R.; FABRE, M. J. M.; TAMUSIUNAS, F. R. Reusabilidade de objetos educacionais. Revista Novas Tecnologias na Educação, Porto Alegre, v. 1, n. 1, p. 1-11, fev. 2003. Disponível em: http:// bit.ly/3iD5DCd. Acesso em: 15 mar. 2015. 